\title{
Physicochemical and electrocoagulation treatment of wastewater from a cardboard packaging company
}

\section{Tratamiento fisicoquímico y por electrocoagulación del agua residual de empresa productora empaques de cartón}

\author{
OLVERA-VALADEZ, Blanca Viviana†, MURILLO-HERNÁNDEZ, Martha Betzabé and PÁRAMO- \\ VARGAS, Javier*
}

Universidad Tecnológica de León. Sustentabilidad para el Desarrollo. Ingeniería en Tecnología Ambiental.

ID $1^{\text {st }}$ Author: Blanca Viviana, Olvera-Valadez / ORC ID: 0000-0002-7373-8271, CVU CONACYT ID: 1095803

ID 1 ${ }^{\text {st }}$ Coathor: Martha Betzabé, Murillo-Hernández / ORC ID: 0000-0001-9146-1125, CVU CONACYT ID: 521401

ID $2^{\text {nd }}$ Coauthor: Javier, Páramo-Vargas / ORC ID: 0000-0003-4022-7050, CVU CONACYT ID: 66460

DOI: $10.35429 / J U R R E .2020 .7 .4 .1 .8$

Received July 11, 2020; Accepted December 03, 2020

\begin{abstract}
The diagnostics of the physicochemical treatment and electrocoagulation plant of the cardboard packaging company showed that currently, the wastewater has a COD of $18,000 \mathrm{mg} / \mathrm{L}$ and suspended solids of $2425 \mathrm{mg} / \mathrm{L}$, therefore, it does not comply with the maximum permissible limits stipulated in nom-001semarnat-1996. It was found that the physicochemical treatment has a removal efficiency of $33 \%$ for COD and $58 \%$ of total solids; while the electrocoagulation stage has a negligible effect. In the physicochemical treatment tests, a removal of $92 \%$ of the COD was obtained and in the treatment by electrocoagulation, a removal of $37.5 \%$ of the residual COD from the previous stage was achieved. This information shows that both treatments can be viable alone or in combination. Objectives: Evaluate the physicochemical treatment and electrocoagulation of wastewater of a company that produces cardboard packaging. Methodology: 1. Develop characterization of wastewater, 2. Develop treatability tests through physicochemical treatment, 3. Develop treatability tests by electrocoagulation treatment, 3. Analyze results. Contribution: This project allowed to know the efficiencies of COD removal, which can be had with the physicochemical treatment, with the treatment by electrocoagulation and with the combined treatment; as well as their optimal conditions in each case. This made it possible to generate operating proposals, which allow reducing operating costs and increasing treatment efficiency.
\end{abstract}

Electrocoagulation, Physicochemical treatment, Combined treatment

\begin{abstract}
Resumen
El diagnóstico de la planta de tratamiento fisicoquímico y de electrocoagulación de la empresa productora de empaques de cartón, mostró que actualmente el agua residual tiene una DQO de $18,000 \mathrm{mg} / \mathrm{L}$ y sólidos suspendidos de $2425 \mathrm{mg} / \mathrm{L}$, por lo que, no cumple con los límites máximos permisibles estipulados en la NOM-001-SEMARNAT-1996. Se encontró que el tratamiento fisicoquímico tiene una eficiencia de remoción del 33\% para DQO y $58 \%$ de sólidos totales; mientras que la etapa de electrocoagulación, tiene un efecto despreciable. En las pruebas de tratamiento fisicoquímico, se obtuvo una remoción del $92 \%$ de la DQO y en el tratamiento por electrocoagulación, se obtuvo una remoción del $37.5 \%$ de la DQO residual de la etapa anterior. Esta información, muestra que ambos tratamientos pueden ser viables solos o combinados. Objetivos: evaluar el tratamiento fisicoquímico y electrocoagulación de aguas residuales de una empresa productora de empaques de carton, 1. Realizar caracterización del agua residual, 2. Desarrollar pruebas de tratabilidad mediante tratamiento fisicoquímico, 3. Desarrollar pruebas de tratabilidad mediante tratamiento por electrocoagulación, 4. Analizar resultados. Contribución: este proyecto, permitió conocer las eficiencias de remoción de dqo, que se pueden tener con el tratamiento fisicoquímico, con el tratamiento por electrocoagulación y con el tratamiento combinado; así como, sus condiciones óptimas en cada caso. Esto permitió generar propuestas de operación, que permiten reducir costos de operación y aumentar la eficiencia de tratamiento.
\end{abstract}

Electrocoagulación, Tratamiento Fisicoquímico, Tratamiento combinado

Citation: OLVERA-VALADEZ, Blanca Viviana, MURILLO-HERNÁNDEZ, Martha Betzabé and PÁRAMO-VARGAS, Javier. Physicochemical and electrocoagulation treatment of wastewater from a cardboard packaging company. JournalUrban-Rural and Regional Economy. 2020. 4-7: 1-8

\footnotetext{
* Correspondence to Author (email: jparamo@utleon.edu.mx)

$\dagger$ Researcher contributing as first author.
} 


\section{Introduction}

Mexico has overexploited aquifers, such as those corresponding to basins in its central and northern areas (Martínez Austria, Delgado Díaz, \& Moeller Chavez, 2019). Guanajuato is a state, located in these referred regions, with a growing extraction of underground water, with an average level of annual abatement of the aquifer of $1 \mathrm{~m}$; result of the deficit between the entry and exit of water in them (Guanajuato State Water Commission, 2019), (CONAGUA, 2018). This deficit is due to the demand of a growing population and industrial development; being the agricultural sector the largest consumer (Guzmán Soria, and others, 2009).

It is important in Mexico and in the world in general, to take measures to seek to guarantee the availability of water, such as wastewater treatment. In 2017, a treatment level of $63 \%$ of municipal wastewater was reported at the national level (CONAGUA, 2018); While, in 2019 , this value for the state of Guanajuato was reported as $95.6 \%$ (Guanajuato State Water Commission, 2019). On the other hand, in relation to industrial wastewater, the level of treatment coverage is lower, as indicated by the value of $16 \%$, reported by Martínez Austria, 2013. Adequate treatment is essential, to enable the reuse of water for consumption human or productive activities and thus contribute to preventing the water problem (Ortega, 2016).

Biological and physicochemical treatment, according to (López, Barrera, Vallejo, \& Barahona, 2008), are traditional treatment options, which can reach pollutant removal levels of around $90-95 \%$; In addition, there are competitive options in terms of efficiency and operating costs, such as electrocoagulation, which allows for removal efficiencies between 50 and $60 \%$; which can be used alone or in combination, seeking to obtain adequate efficiency.

This project was carried out in a company dedicated to the design, manufacture and delivery of cardboard, plastic and wood packaging and accessories; that generates waste water with a high pollutant load, with values of chemical oxygen demand (COD), around 18000 $\mathrm{mg} / \mathrm{L}$. This wastewater is currently treated in batches, by means of a physicochemical treatment and electrocoagulation.
Interferences between the 2 types of treatment have been observed, such as sludge drag, which affects its efficiency; Furthermore, there is no reference to the expected efficiency of each stage. In this project, the company's wastewater treatment was evaluated through physicochemical treatment, through electrocoagulation treatment and through the combined treatment of both types; in order to generate proposals for improvement.

\section{Theoretical framework}

The human being throughout history has been in contact with the environment, to survive, obtaining natural resources. Currently, the abuse in their use has caused effects (Cardona, 2019), which even exceed their capacity for recovery (Toscano, 2005); As is the case of water, whose excessive consumption has caused overexploitation problems in recent decades and a decrease in water resources, which is alarming, since it is considered the most important resource for human beings and that it cannot be generated or achieved in a simple way (Ambientum, 2018).

The land is made up of $70.8 \%$ of its surface by water, of which only about $3 \%$ is fresh water, that is, suitable for human consumption, due to the low concentration of minerals. Of the $3 \%$ of fresh water, you only have access to $0.5 \%$, since the rest is found in places that are difficult to access, such as glaciers. On the other hand, it must be considered that part of the fresh water to which one has access suffers some type of contamination or is destined to industrial activities necessary for human development. If the misuse of water continues, the depletion of this resource is expected by 2050 (Cubadebate, 2016); which poses a difficult scenario, since water is a road for human beings (Paredes Díaz, 2013). Industrial development allows satisfying needs, socioeconomic activity and improvements in the quality of life of the population, but affects, among others, the quality of water (Suárez Tamayo \& Molina Esquivel, 2014), due to pollution, which transforms it into water residual. Waste water is that which has undergone changes or modifications by humans and generally has the presence of chemical substances or microorganisms that pose a risk to production processes or to human health (EcoIntellutions, 2019). 
Its components can be physical, chemical and biological; which determines the type of treatment; that is, the way in which the pollutants present in said waters are separated, or how they are transformed into simpler compounds (Rodríguez, 2016). The approach of this type of solutions contributes to sustainable development (García, 2018).

Wastewater treatment consists of the removal of pollutants, through physical, chemical and biological processes, which are chosen based on the characteristics of the pollutants. Within the framework of a treatment train, these processes can appear as part of pretreatment, primary, secondary or tertiary treatment. In the first, large or heavy solids are removed; in the second, sedimentable solids, in the third, organic matter is degraded and suspended solids are eliminated, and in the tertiary, disinfection is carried out (EcuRed, 2015).

The physicochemical treatment has two stages, coagulation and flocculation; In the first, the nature of the colloidal or suspended solids, their electrical charge, is altered, forming flocs or aggregates of material; which in the second stage finish their formation and are removed by sedimentation or flotation (García, 2018), (Andía, 2000).

Electrocoagulation is a wastewater treatment process, in which electrical energy is used, which is induced in the wastewater, through metal plates, usually aluminum and iron, called electrodes. When aluminum acts as anode and cathode, its reactions are the following (Restrepo Mejía, Arango Ruiz, \& Garcés Giraldo, 2006), (Arango Ruiz, 2005):

At the anode:

$$
\begin{aligned}
& \mathrm{Al} \rightarrow \mathrm{Al}^{+3}+3 \mathrm{e}^{-} \\
& \mathrm{Al}^{+3}(\mathrm{ac})+3 \mathrm{H}_{2} \mathrm{O} \rightarrow \mathrm{Al}(\mathrm{OH})_{3(\mathrm{~s})}+3 \mathrm{H}^{+}(\text {ac }) \\
& \mathrm{nAl}(\mathrm{OH})_{3} \rightarrow \mathrm{Al}_{\mathrm{n}}(\mathrm{OH})_{3 \mathrm{n}}
\end{aligned}
$$

At the cathode:

$$
3 \mathrm{H}_{2} \mathrm{O}+3 \mathrm{e}^{-} \rightarrow 3 \mathrm{H}_{2(\mathrm{~g})}+3 \mathrm{OH}^{-}
$$

The electric current allows metal ions to be generated at the anode (reaction 1), which act as a coagulant (reactions 2 and 3 ).
This electrode runs out as it dissolves, therefore it is called a sacrificial electrode (Restrepo Mejía, Arango Ruiz, \& Garcés Giraldo, 2006). On the other hand, at the cathode, there is a reduction, generating hydrogen gas (reaction 4); which contributes to the separation of the flocs generated. The main factors of electrocoagulation, with: a) $\mathrm{pH}$ : it has been reported that the best results are found at a $\mathrm{pH}$ close to 7 ; b) current density: it is related to the current and the area of the electrodes; for each case the optimum value must be determined; for example, an excess of current, means a greater expense, efficiency problems and loss of energy as heat; c) conductivity: it is an important factor, as it facilitates the conduction of current and reduces the required voltage; d) temperature: it is reported that at $60^{\circ}$ $\mathrm{C}$, there is maximum efficiency (Restrepo Mejía, Arango Ruiz, \& Garcés Giraldo, 2006), (Arango Ruiz, 2005).

Electrocoagulation is able to remove high contents of biochemical oxygen demand (BOD) and COD, as well as fats and oils (GyA). The main industries that use this process are electroplating, packaging factories, the paper industry, and refineries. Its costs that have been reported are lower than a physicochemical treatment and generate less sludge (Restrepo Mejía, Arango Ruiz, \& Garcés Giraldo, 2006).

\section{Materials and methods}

To evaluate the treatments, it was necessary to perform jar tests and electrocoagulation tests at the laboratory level. For this it was necessary to use the following materials and equipment.

\subsection{Materials and reactives}

In the diagnosis stage, the residual water was obtained, from the entrance to the physicochemical treatment, the exit thereof, the exit from the electrocoagulation treatment and from the treated water tank. The samples were preserved and stored at $4{ }^{\circ} \mathrm{C}$ and a $\mathrm{pH} \leq 2$, as the case may be. 
For the analysis of water, the following reagents were used: potassium dichromate $\left(\mathrm{K}_{2} \mathrm{Cr}_{2} \mathrm{O}_{7}\right)$, MEYER brand with a purity of 99.0\%; silver nitrate $\left(\mathrm{AgNO}_{3}\right)$, brand $\mathrm{MEYER}$ with a purity of $98.0 \%$; silver sulfate $\left(\mathrm{Ag}_{2} \mathrm{SO}_{4}\right)$, brand MEYER with a purity of $98.0 \%$; Mercury Sulfate II $\left(\mathrm{HgSO}_{4}\right)$, brand MEYER with a purity of 99.5-98.0\%; ferrous sulfate heptahydrate $\left(\mathrm{FeSO}_{4} \cdot{ }_{7} \mathrm{H}_{2} \mathrm{O}\right), \mathrm{MEYER}$ brand with a purity of 99.0\%; concentrated sulfuric acid $\left(\mathrm{H}_{2} \mathrm{SO}_{4}\right)$, MEYER brand with purity of 95-98\%; concentrated hydrochloric acid $(\mathrm{HCl})$, MEYER brand with $90 \%$ purity, potassium biphthalate $\left(\mathrm{C}_{8} \mathrm{H}_{5} \mathrm{KO}_{4}\right)$, MEYER brand with $95-99 \%$ purity, ammoniacal ferrous sulfate hexahydrate $[\mathrm{Fe}$ $\left.\left(\mathrm{NH}_{4}\right)_{2}\left(\mathrm{SO}_{4}\right)_{2.6} \mathrm{H}_{2} \mathrm{O}\right]$, MEYER brand, 98.5$100 \%$ purity and distilled water.

For the jar tests, the raw water sample was taken on the day of the tests. For the physical-chemical treatment solutions of calcium hydroxide $\left(\mathrm{Ca}(\mathrm{OH})_{2}\right)$, aluminum sulfate $\left(\mathrm{Al}_{2}\left(\mathrm{SO}_{4}\right)_{3}\right)$, and a polymer solution were prepared. The quality of the treated water was monitored, analyzing COD; so the reagents already referred to were used.

For the electrocoagulation tests, two aluminum plates $8 \mathrm{~cm}$ long by $6 \mathrm{~cm}$ wide and 2 $\mathrm{mm}$ thick were used as electrodes. Two PVC tubes were used as support to avoid any type of interference during the treatment; 4 small slots were made in the first one, 2 to hold the plates and 2 to hold the system inside the container with water (figure 1), with a separation between electrodes of $2 \mathrm{~cm}$. The second tube should only have a tube length of $2 \mathrm{~cm}$ to prevent the plates from having contact with each other.

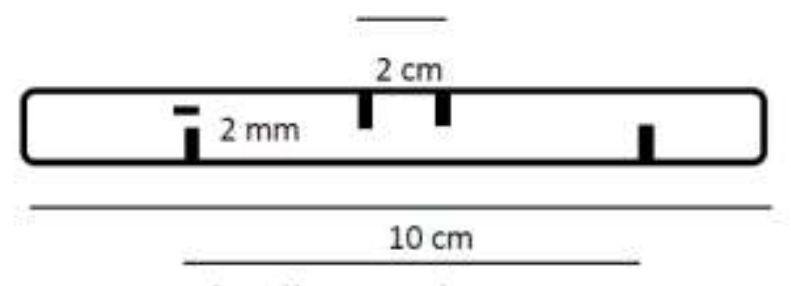

Beaker diameter plus $2 \mathrm{~mm}$

Figure 1 PVC tube, used as electrode holder

\subsection{Equipment}

In the jar tests, a stirrer, TEMSA brand was used; 3 speeds were used, $180 \mathrm{rpm}$ (high), $100 \mathrm{rpm}$ (medium) and $45 \mathrm{rpm}$ (low). In the electrocoagulation tests, a power source, brand BK PRECISION, was used.
In the laboratory determinations, a $\mathrm{HACH}$ brand COD test digester, a FELISA brand muffle, a FELISA brand drying oven and a VELAB VE-210 brand analytical balance with a capacity of $210 \mathrm{gr}$ and a sensitivity of \pm 0.0001 were used. $\mathrm{g}(0.1 \mathrm{mg})$.

\subsection{Analysis methodologies}

The field parameters $\mathrm{pH}$ (NMX-AA-008-SCFI2000) and conductivity (NMX-AA-093-SCFI2000) were carried out, after each sampling. In the diagnosis of the treatment of the real process, analysis of COD (NMX-AA-030/2-SCFI-2011), fats and oils (NMX-AA-005-SCFI-2013), solid (NMX-AA-034 -SCFI-2015) and sedimentable solids (NMX-AA-004-SCFI-2000), to the samples of raw water and treated water. In the case of the samples from the physicochemical and electrocoagulation treatment, only COD and solids were analyzed.

In relation to the jar tests, at the laboratory level, during development turbidity of the supernatant water, sedimentable solids and sedimentation speed were measured; in addition to observations of the flocs and their compaction. The samples of the tests selected as the best were analyzed COD and sedimentable solids (SSe).

\subsection{Treatment systems}

For the physicochemical treatment, a 6-unit jar test shaker was used (Figure 2). The equipment has a speed control from 50 to $300 \mathrm{rpm}$.

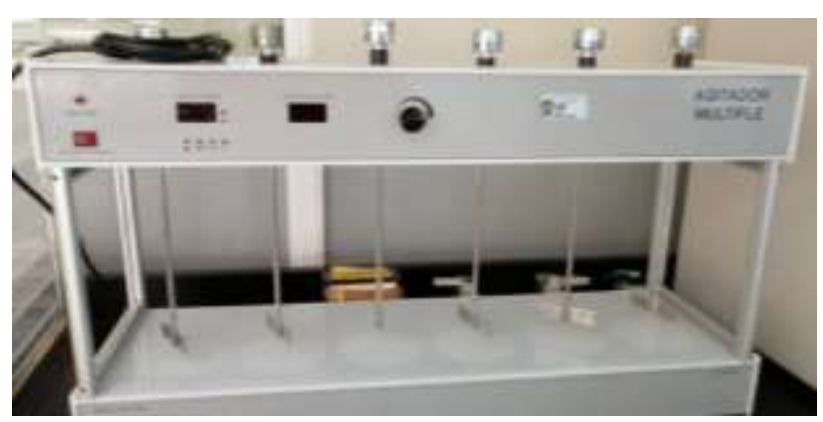

Figure 2 Jar test shaker

During the physicochemical treatment, calcium hydroxide was first added at a high speed for $3 \mathrm{~min}$, then aluminum sulfate was added stirring at a medium speed, $5 \mathrm{~min}$ and finally, the polymer was added at a low speed, stirring. for $5 \mathrm{~min}$ (Figure 3). 


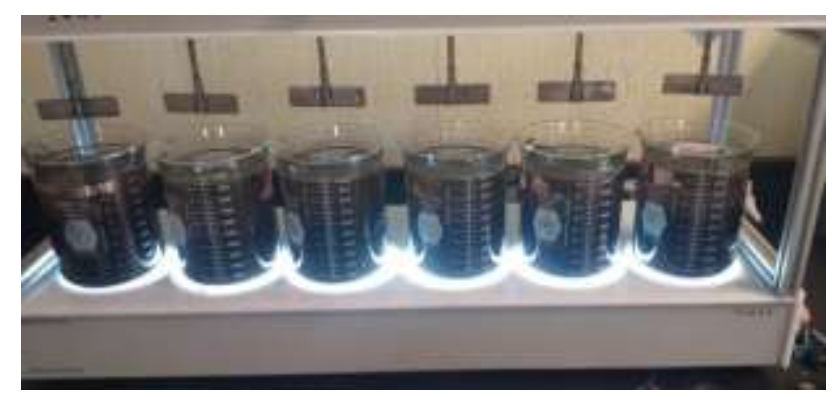

Figure 3 Physicochemical treatment

In the case of the electrocoagulation tests, the water to be treated was the water from the physicochemical treatment; with optimal $\mathrm{pH}$ and dosage conditions found in jar tests. The system shown in Figure 4 was used, with a $1 \mathrm{~L}$ volume reactor, a power source and two aluminum electrodes.

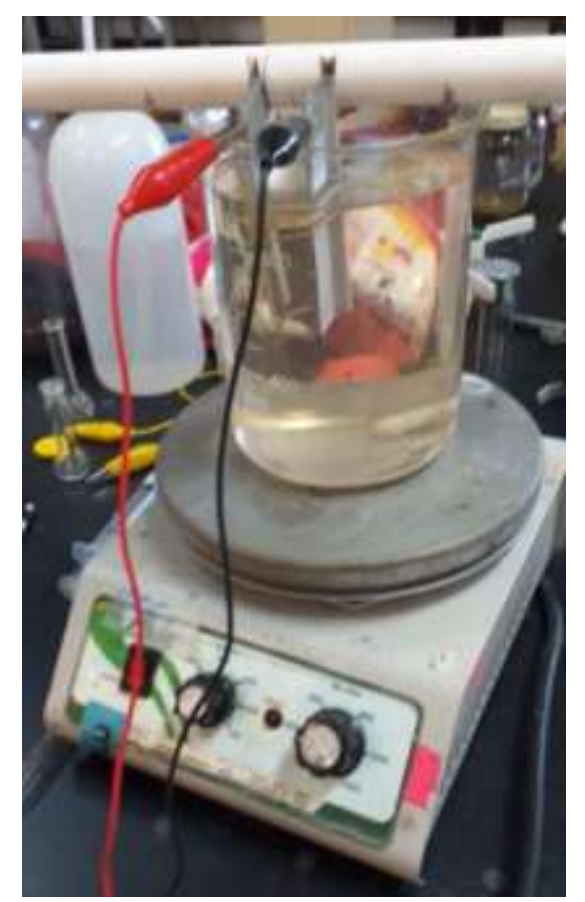

Figure 4 Electrocoagulation treatment system

The supply power is $120 \mathrm{~W}$ and an output current of 0-3 A, 0-30 V (Figure 5).

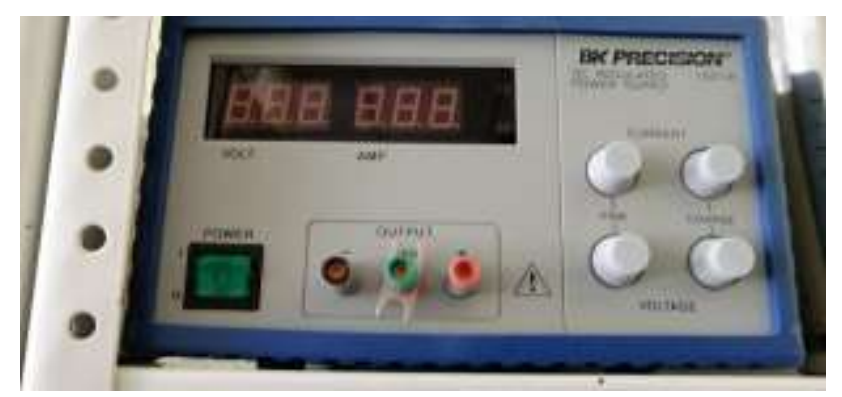

Figure 5 Power supply
The dimensions of the electrodes were 8 $\mathrm{cm}$ long, $6 \mathrm{~cm}$ wide and $2 \mathrm{~mm}$ thick; with an extension, to connect the cables, in order to reduce interference in the treatment (Figure 6).

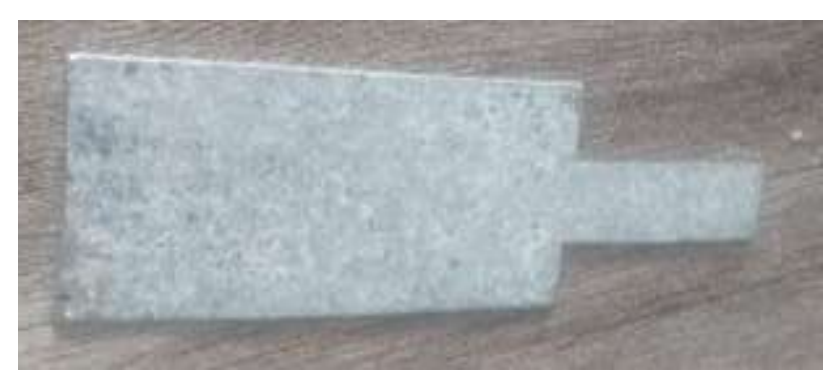

Figure 6 Electrodes

\section{Results}

\section{Diagnosis}

The results of the characterization of COD and solids $(\mathrm{ST}=$ total solids, $\mathrm{STV}=$ total volatile solids and STF = total fixed solids), of the wastewater at different points of the current treatment train, are presented in tables 1 and 2.

\begin{tabular}{|l|c|}
\hline \multicolumn{1}{c}{ Sample } & COD \\
\hline Raw water & $18000 \mathrm{mg} / \mathrm{L}$ \\
\hline Effluent from physicochemical treatment & $12000 \mathrm{mg} / \mathrm{L}$ \\
\hline Effluent from electrocoagulation treatment & $15000 \mathrm{mg} / \mathrm{L}$ \\
\hline Final effluent & $15000 \mathrm{mg} / \mathrm{L}$ \\
\hline
\end{tabular}

Table 1 COD analysis results

\begin{tabular}{|l|r|r|r|}
\hline \multicolumn{1}{|c}{ Sample } & \multicolumn{1}{c}{$\begin{array}{c}\text { ST } \\
(\mathrm{mg} / \mathrm{L})\end{array}$} & \multicolumn{1}{c|}{$\begin{array}{c}\text { STV } \\
(\mathrm{mg} / \mathrm{L})\end{array}$} & \multicolumn{1}{c|}{$\begin{array}{c}\text { STF } \\
(\mathrm{mg} / \mathrm{L})\end{array}$} \\
\hline Raw water & 14990 & 12970 & 2020 \\
\hline $\begin{array}{l}\text { Effluent from physicochemical } \\
\text { treatment }\end{array}$ & 6330 & 1350 & 4980 \\
\hline $\begin{array}{l}\text { Effluent from } \\
\text { electrocoagulation treatment }\end{array}$ & 6940 & 4030 & 2910 \\
\hline Final effluent & 6310 & 2640 & 3670 \\
\hline
\end{tabular}

Table 2 Solid Analysis Results

The analysis of the data from Table 1 and 2 shows that a removal efficiency was found in the physicochemical stage and in the complete process, in COD, of $33 \%$ and $16.6 \%$ respectively; while, in total solids, the values were $57.8 \%$ and $57.9 \%$ respectively. The sedimentable solids values were, for raw water, $50 \mathrm{~mL} / \mathrm{L}$, physicochemical treatment water; $150 \mathrm{~mL} / \mathrm{L}$, electrocoagulation treatment water, $50 \mathrm{~mL} / \mathrm{L}$ and final effluent water, $0 \mathrm{~mL} / \mathrm{L}$. In fats and oils, values of $10023 \mathrm{mg} / \mathrm{L}$ were obtained in the raw water and $487 \mathrm{mg} / \mathrm{L}$ in the final effluent. In general, the efficiency of the current treatment is low. 
An increasing variation of $\mathrm{COD}$ is observed between the effluent of the physicochemical treatment and the final effluent.

\section{Jug test}

For the physicochemical treatment, the optimum $\mathrm{pH}$ was first identified. In Table 3, the results of the tests are presented, performed with a constant dose of $12500 \mathrm{mg} / \mathrm{L}$ of $\mathrm{Al} 2\left(\mathrm{SO}_{4}\right)_{3}$ and $6250 \mathrm{mg} / \mathrm{L}$ of $\mathrm{Ca}(\mathrm{OH})_{2}$; chosen as starting dose; close to the values used in the company $14280 \mathrm{mg} / \mathrm{L}$ of $\mathrm{Al}_{2}\left(\mathrm{SO}_{4}\right)_{3}$ and $7140 \mathrm{mg} / \mathrm{L}$ of $\mathrm{Ca}(\mathrm{OH}) 2$.

\begin{tabular}{|c|c|c|c|c|}
\hline Sample & pH & $\begin{array}{c}\% \text { Turbidity } \\
\text { Removal (RT) }\end{array}$ & $\begin{array}{l}\text { Settling solids } \\
(\mathrm{mL} / \mathrm{L})\end{array}$ & $\begin{array}{c}\text { COD } \\
(\mathrm{mg} / \mathrm{L})\end{array}$ \\
\hline 1 & 5 & 99.8 & 700 & 3300 \\
\hline 2 & 6 & 99.8 & 600 & 2340 \\
\hline 3 & 7 & 99.8 & 700 & 3000 \\
\hline 4 & 8 & 99.5 & 800 & 3600 \\
\hline 5 & 9 & 99.4 & 800 & 4740 \\
\hline
\end{tabular}

Table 3 Optimal pH results

The results obtained showed that with $\mathrm{pH}$ 6 , the best removal efficiency was obtained, with $87 \%$ of COD and $99.8 \%$ in turbidity. Once the optimal $\mathrm{pH}$ was obtained, the optimal dose was identified; performing 6 tests, the results of which are shown in Table 4.

\begin{tabular}{|c|c|c|c|c|c|}
\hline Sample & $\begin{array}{c}\mathrm{Ca}(\mathrm{OH}) \\
2 \text { dose } \\
(\mathrm{mg} / \mathrm{L})\end{array}$ & $\begin{array}{c}\mathrm{A} 12 \text { (SO4) } \\
3 \text { dose } \\
(\mathrm{mg} / \mathrm{L})\end{array}$ & $\% \mathrm{RT}$ & $\begin{array}{c}\text { Sólidos } \\
\text { sedimentables } \\
(\mathrm{mL} / \mathrm{L})\end{array}$ & $\begin{array}{c}\text { DQO } \\
(\mathrm{mg} / \mathrm{L})\end{array}$ \\
\hline 1 & 3500 & 7000 & 99.8 & 700 & 2880 \\
\hline 2 & 4000 & 8000 & 99.8 & 650 & 1800 \\
\hline 3 & 4500 & 9000 & 99.9 & 600 & 1740 \\
\hline 4 & 5000 & 10000 & 99.9 & 500 & 1440 \\
\hline 5 & 5500 & 11000 & 99.8 & 800 & 1500 \\
\hline 6 & 6250 & 12500 & 99.9 & 600 & 2280 \\
\hline
\end{tabular}

Table 4 Results of obtaining optimal dose

The results show that, in test 4 , the maximum removal efficiencies were obtained, with $92 \%$ COD and $99.9 \%$ turbidity, therefore, they were considered as optimal doses. The flocs were well formed and easily sedimented.

\section{Electrocoagulation}

The water to be treated for these tests was that from the physicochemical treatment, under the optimal conditions found; with a COD of 4800 $\mathrm{mg} / \mathrm{L}$, a different value from that referred to in Table 4, due to the changing characteristics of the wastewater, depending on the production process. 3 different streams were used for the treatment; in order to analyze its effect.
The analyzes carried out were settling solids, turbidity and COD. Samples were taken at 10, 20 and $30 \mathrm{~min}$, to analyze the efficiency of the treatment and its behavior over time, in removal of COD. The behavior is shown in Figure 7.

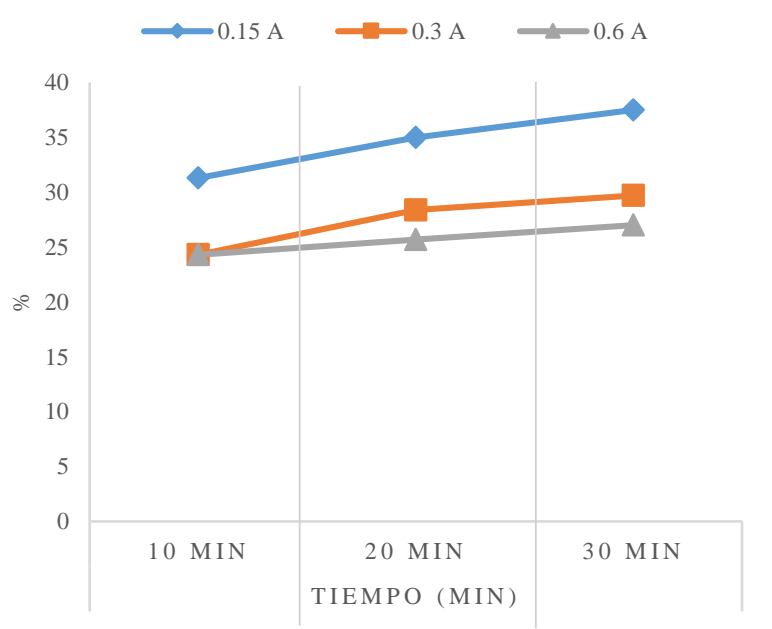

Figure 7 Percentage of COD removal in electrocoagulation tests

The behavior of the COD removal percentage, from Figure 7; shows that the best removal condition was obtained with a current condition of $0.15 \mathrm{~A}$ and at a time of 30 minutes; with a turbidity removal value of $3.7 \%$ and in COD of $37.5 \%$ and a voltage variation between 15 and $18 \mathrm{~V}$. The best COD removals, of the currents of 0.3 and $0.6 \mathrm{~A}$, were at 30 minutes, with values of $30 \%$ and $27 \%$, respectively.

The results of the electrocoagulation tests show that it is a quick process. The retention time of 30 minutes is considered adequate, since as can be seen, in this period, the processes tend to be stable. In the 3 tests, an average value of settleable solids of $10 \mathrm{~mL} / \mathrm{L}$ was obtained; low value, congruent with the observed low COD removal. Regarding the effect of current, the best condition found, 0.15 A; It has the advantage, in addition to having the lowest operating cost.

A combined treatment test was carried out in the company, applying the optimal conditions found at the laboratory level and qualitatively the results showed good quality of the treated water; with raw water that turned from grayish and without transparency to colorless water with good transparency. 
The global process shows that, with an adequate operation, the greatest removal of COD occurs in the physicochemical stage; so it can be considered to operate the treatment plant with only this process.

\section{Conclusions}

The laboratory evaluation allowed to determine that with a dose of $50,000 \mathrm{mg} / \mathrm{L}$ for calcium hydroxide and $10,000 \mathrm{mg} / \mathrm{L}$ for aluminum sulfate higher removal efficiencies are obtained compared to those obtained in the diagnosis. Comparison of these values with the operating conditions of the real plant, of $7140 \mathrm{mg} / \mathrm{L}$ of Ca (OH) 2 and $14280 \mathrm{mg} / \mathrm{L}$ of Al2 (SO4) 3, show that the application of these optimal conditions found can represent an estimated saving of 30\%, in both substances. It was found that the physicochemical treatment allows to obtain the highest pollutant removal, up to $92 \%$; Therefore, it is possible to choose to operate only this stage; saving operating costs by adjusting the doses of chemicals used and eliminating the electrocoagulation stage.

On the other hand, the experimentation showed that the electrocoagulation treatment works for the type of water of interest; even after the physicochemical treatment, a COD removal was obtained, up to $37.5 \%$. It is recommended to evaluate the use as a method of treating raw water, by electrocoagulation only and to compare operating costs.

\section{Acknowledgments}

We thank the packaging production company for allowing access to its facilities and its support for the realization of this project. We also thank the Technological University of León, for its support in facilities and resources.

\section{References}

Ambientum. (2018). El consumo de agua en porcentajes. Obtenido de https://www.ambientum.com/enciclopedia_med ioambiental/aguas/el-consumo-de-agua-enporcentajes.asp

Andía, Y. (Abril de 2000). Tratamiento de agua. Coagulación y Floculación. Obtenido de http://www1.frm.utn.edu.ar/archivos/civil/Sanit aria/Coagulaci\%C3\%B3n\%20y\%20Floculaci\% C3\%B3n\%20del\%20Agua\%20Potable.pdf
Arango Ruiz, Á. (1 de Junio de 2005). La electrocoagulación: una alternativa para el tratamiento. Obtenido de https://www.redalyc.org/pdf/695/69520109.pdf

Cardona, A. (2019). Qué es el medio ambiente: definición y resumen. Obtenido de https://www.ecologiaverde.com/que-es-elmedio-ambiente-definicion-y-resumen1674.html

Comisión Estatal del Agua de Guanajuato. (Febrero de 2019). Situación hídrica y disponibilidad en el Estado de Guanajuato. Obtenido

de

http://jumapac.com/documentos/FORO\%20ES TUDIANTIL/FUENTES\%20DE\%20CONSUL TA/situacion_agua_gto_extensa.pdf

CONAGUA. (2018). Estadisticas del Agua en México 2018. Obtenido de $\mathrm{http} / / /$ sina.conagua.gob.mx/publicaciones/EAM _2018.pdf

Cubadebate. (2 de Mayo de 2016). Despilfarro conduciría a agotamiento de agua potable en el mundo antes de 2050. Obtenido de http://www.granma.cu/ciencia/2016-05-

02/despilfarro-conduciria-a-agotamiento-deagua-potable-en-el-mundo-antes-de-2050-0205-2016-14-05-

43\#: :text=Despilfarro\%20conducir\%C3\%ADa $\% 20 \mathrm{a} \% 20$ agotamiento\%20de $\% 20$ agua\%20pota ble $\% 20$ en $\% 20$ el $\% 20$ mundo $\% 20$ antes $\% 20$ de $\% 2$ 02050,

Eco-Intellutions. (13 de Febrero de 2019). Tipos de Aguas Residuales, ¿cuántos existen y qué contienen? Obtenido de http://www.ecointell.com.mx/plantas-detratamiento-de-agua/tipos-de-aguas-residualescuantos-existen-y-que-contienen

EcuRed. (2015). Tratamiento de aguas residuales. Obtenido de https://www.ecured.cu/Tratamiento_de_aguas_r esiduales

García, A. (6 de Agosto de 2018). Tipos de tratamiento de aguas residuales. Obtenido de https://www.ecologiaverde.com/tipos-detratamiento-de-aguas-residuales-1448.html 
Guzmán Soria, E., Hernández Martínez, J., García Salazar, J. A., Rebollar Rebollar, S., de la Garza Carranza, M. T., \& Hernández Soto, D. (7 de Noviembre de 2009). CONSUMO DE AGUA SUBTERRÁNEA EN GUANAJUATO, MÉXICO. Obtenido de https://www.redalyc.org/pdf/302/30215548009. pdf

INEGI. (2019). Directorio de empresas y establecimientos.

Llano, B. A., Cardona, J. F., Ocampo, D., \& Ríos, L. A. (7 de Noviembre de 2013). Tratamiento Fisicoquímico de las Aguas Residuales Generadas en el Proceso de Beneficio de Arcillas y Alternativas de Uso de los Lodos Generados en el Proceso. Obtenido de https://scielo.conicyt.cl/pdf/infotec/v25n3/art10. pdf

López, L., Barrera, F., Vallejo, R., \& Barahona, A. (2008). Estudio comparativo entre un proceso fisicoquímico y un biológico para tratar agua residual de rastro. Interciencia.

Martínez Austria , P., Delgado Díaz, C., \& Moeller Chavez, G. (2019). Seguridad hídrica en México: diagnóstico general y desafios principales. Obtenido de https://polipapers.upv.es/index.php/IA/article/vi ew/10502

Martínez, A. (2013). Los retos de la seguridad hídrica. Tecnología y Ciencias del Agua, 165180.

Ordoñez, J. (2011). Ciclo Hidrológico. Obtenido de

https://www.gwp.org/globalassets/global/gwpsam_files/publicaciones/varios/ciclo_hidrologic o.pdf

Ortega, R. R. (16 de Diciembre de 2016). Prevención y resolución de conflictos en torno al agua ante la construcción de obras hídricas: Un caso de negación de agenda en México. Obtenido https://www.redalyc.org/pdf/2815/Resumenes/ Resumen_281548814004_1.pdf

Paredes Díaz, J. (2013). IMPORTANCIA DEL AGUA. Obtenido de https://www.usmp.edu.pe/publicaciones/boletin /fia/info86/articulos/importanciaAgua.html
Posada, N. B. (27 de A bril de 2010). SISTEMA DE ELECTROCOAGULACIÓN COMO TRATAMIENTO DE AGUAS RESIDUALES GALVÁNICAS. Obtenido de http://www.scielo.org.co/pdf/cein/v20n1/v20n1 a03.pdf

Restrepo Mejía, A. P., Arango Ruiz, Á., \& Garcés Giraldo, L. (23 de Marzo de 2006). La Electrocoagulación: retos y oportunidades en el tratamiento de aguas. Obtenido de http://repository.lasallista.edu.co/dspace/bitstrea m/10567/514/1/pl_v1n2_58-

77_electrocoagulacion.pdf

Rodríguez, C. (2016). Tipos de aguas residuales: por qué es importante conocerlas. Obtenido de https://www.hidrotec.com/blog/tipos-de-aguasresiduales/

SEMARNAT. (2015). POBLACIÓN Y MEDIO AMBIENTE. Obtenido de https://apps1.semarnat.gob.mx:8443/dgeia/infor me15/tema/cap1.html

Suárez Tamayo, S., \& Molina Esquivel, E. (2014). El desarrollo industrial y su impacto en el medio. Revista Cubana de Higiene $y$ Epidemiología, 7.

Toscano, J. C. (7 de Noviembre de 2005). El agotamiento de recursos. Obtenido de http://www.madrimasd.org/blogs/CTSiberoame rica/2005/11/07/9031

Tuset, S. (2010). HISTORIA SOBRE EL TRATAMIENTO DEL AGUA POTABLE. Obtenido de https://blog.condorchem.com/historia-sobre-eltratamiento-del-agua-potable/

Tuset, $\quad$ S. $\quad$ (2014). $\quad L A$ ELECTROCOAGULACIÓN, UN TRATAMIENTO ECONÓMICO Y EFICAZ PARA LAS AGUAS RESIDUALES. Obtenido de https://blog.condorchem.com/electrocoagulacio n-aguas-residuales/ 